\title{
REFORMULATION OF LEARNING AND TEACHING HISTORY AT ELEMENTARY AND SECONDARY LEVEL OF EDUCATION
}

\author{
Zulfikri Anas ${ }^{1}$
}

\begin{abstract}
Past, present, and future are continuous processes of life. However, as people are not able to look clearly into the future, but they have to prevent to make a same mistake, people must learn history appropriately. Since the phenomenon of life goes through uninterrupted processes, people should be able to predict the future by dealing with past-to-present happenings wisely. This is called "historical competencies". The focus of learning and teaching history is to make students able to appreciate the journey of life in the context of historical education so that they are able to build a better future, individually or within a community or a country in responsible manners. To acquire the ability, learning and teaching process of history should be reformulated by organizing materials in the curriculum, textbooks, and learning and teaching strategies. In this moment, history is "the center" of social science education, as implemented in several developed countries. Each social science subject is oriented to create an understanding about historical development of particular countries with the intention that students are able to appreciate it. Therefore, they will be encouraged to be good citizens and responsible for granting a better future for the next generation. Furthermore, this reformulation will make history courses more valuable to create a better life in the forthcoming.
\end{abstract}

Key words: historical education, historical competencies, curriculum, learning materials, learning strategies.

\section{Introduction}

Each happening in human life is reality. Past and present facts cannot be denied and future events are forms of direct consequences and can be considered as "postponed reality". As a result, people will not be able to run from it, but they may be able to reduce or avoid its negative effects. Accordingly, each person should have ability in appropriately dealing with the effects and wisely appreciating the values of life. The ability can only be acquired if someone is able to appreciate "history" properly. This is in line with proverbs saying, "a fox is not taken twice in the same snare" or "it is a silly fish, that is caught twice with the same bait". Those imply that historical competencies are necessary for each individual to maintain and improve the quality of future life.

1 Zulfikri Anas., The Center of Curriculum, Board of Research and Development (Balitbang), Ministry of National Education (Kemendiknas). This Article has been reviewed by Prof. Dr. Susanto Zuhdi (Indonesia University) and Dr. Nana Supriatna, M.Ed (Indonesia University of Education). 
The main goal of history courses is to create wise, prudent and optimistic attitudes in dealing with upcoming challenges. Anticipating the worst possibilities is a proficiency needed to embrace the future. In starting a business, for instance, a person should be ready to deal with the greatest risks that might happen. This attitude will make one's personality stronger. Predicting the risks requires competencies in interpreting past events, personal or someone else's experiences, and the development of the real world and knowledge. The competencies needed are historical competencies. The same reason becomes the basis for expanding the scope of historical courses, besides politics and nationality aspects.

Since the phenomenon of life goes through never-ending processes, people should be able to predict the future by dealing with past-to-present happenings wisely. This is called "historical competencies". In this forum, I will discuss historical materials since they belong to historian's capacity. I will focus on how each student acquires competencies in the context of historical education so that other people will gain historical competencies. Hence, it is expected that they will be able to accept profound wisdoms from the past events in making a right decision for fighting for the present time and saving the future life.

Therefore, the entire historical facts and important events in human life should be valued properly and objectively. Appreciation skills through objective interpretation will counter the subjective perception from historical events. So that, "history reconstruction" is unnecessary, but the interpretation should be reconstructed. This way of thinking should be developed though appropriate learning and teaching process.

Achieving the ability will be difficult as long as the process of learning and teaching history is still monotonous. Students learn history under duress. Another point is that the materials seem like nostalgia stories, which do not describe the values of life. Moreover, history courses are limited to political and nationality histories, which are considered to provide more doctrines than logical reasoning. This condition gets worse as the interpretation of historical events is inclined to unilateral interest and students are "not allowed" to interpret them from different, or conflicting, points of view. Positive examples given seem to be forcefully described to become knowledge, not as sufficient consideration reflected in one's behaviors.

Furthermore, as students become more adult, they will ignore the values of history and good models. This is reflected from behaviors among common people, including those elected as the government of the country. They behave in contrast to their words, and the good precedent is typically ignored. The unacceptable behavior is also shown by those maintaining historic sites. Historic happenings, artifacts, and documents seem to be valued as "playthings" or "entertaining objects" and are even put up for sale. Historian's thoughts are frequently beaten down by the arguments of those acting "to accelerate the development". Just at a certain time, there was a decision to destruct the ancient temples of Muara Takus in Koto Panjang, Riau Province. Tens or hundreds of temples surrounding are 
going to be "flattened" to build an electric power station. Unfortunately, similar happenings occur at other places. Historic sites are simply considered as the sources of foreign exchanges and if they are not of use, they will be ignored and become much less valuable.

\section{The Failure of Historiography}

The growth of such inconsistent behaviors is also related to the failure of history curriculum along with learning and teaching process at the elementary level of education. History courses given tend to be subjected as forms of frustrating recitation and indoctrination. Teachers and textbooks merely deliver the materials as a series of years and events to be memorized and summoned up in the final examination. This is still happening today. In the perspective of Critical Pedagogy, that method of learning and teaching history is only used to be of interest of men in power, ruling elites, curriculum designer, etc. and it will take no notice of students' role as the figures of the generation (Anggara, 2007, in Martanto, 2009).

This process shows lack of interpretation, alternative thoughts, and just takes on history courses as a form of indoctrination. The condition gets worse as a result of narrow-minded understanding on historical education that is easily interfered by political interest of privileged elites. Moreover, history courses are used as political and justifiable means. Governmental replacement has an effect on the reconstruction of history courses and it makes numerous students and the public confused. The wrongs can be the rights in perspectives of new governing elites, and it arises the term of "history reconstruction". Whereas, history does not need to be reconstructed, but one's ways of thinking in interpreting historical events from a figure or a set of people do, so that the interpretation will be free from subjective importance.

This condition is closely related to the failure of historiography of Indonesia. One of the causes is subjective understanding and interpretation on historical events. For some sovereign rulers, historiography is a means to strengthen their power, and for others it is a means to show disrespect and using past events to construct a social justification (Purwanto, 2006)". Nonetheless, the justification must be based on their own self-interest.

The failure of historiography reflects that not only common people, but also historiography experts and prominent figures have difficulties in interpreting the values of historical facts. In composing historical scripts, narrow sense of nationality influences one's ways of thinking and interpreting a historical event. In his writing entitled 'Gagalnya Historiografi Indonesiasentris?!' (2006), Purwanto describes, "history seems to be constructed as an indulgence for nationality enthusiasm without considering further dimensions that construct the history of the nation. Historiography of Indonesia is trapped in the concept of 
"Indonesianization", "nationalization", and "authentication" of history. A pilledon matter about the acknowledgement of using the word "Indonesia" to replace "Hindia Belanda" in the historiography of Indonesia in the colonial era, as well as a discussion about national movement, is an example for the confusion, despite the fact that all people in that era had not ever known the word "Indonesia" as we all recognize it today" (ibid).

Furthermore, Purwanto explains, "a precise failure of historiography is the inadequacy of Indonesia-centric tradition to reveal citizen past events, history of daily life, humanistic history, explanation varieties, and epistemological varieties and to be independent from colonial historical heritage and its viewpoint a history means political history. Many individuals or communities do not have or are regarded not to have history, although they have past times. Consequently, particular terms exist; such as community without history, history without community, women without history, or history without women. History becomes elitism and formalism, which do not have something to do with daily life, humanity, and abandoned matters" (ibid).

Indonesia-centric historiography tends to be narrow-minded and does not open up any possibilities for alternative perspectives. Moreover, it can be said that most of today's past times of Indonesia are constructed and interpreted in the same way through conservative ways of thinking from historiography tradition of colonial-centric. Similar condition is reflected in today's complexity to determine past events and history of the nation. The term of "history of reconstruction" is a notable instance for it. Initially, the term is used to construct alternative discourses and scripts of history in overcoming the politics of indoctrination history and military dogma of New Order (Orde Baru) and Soeharto regime. However, recent phenomenon captivatingly suggests that the term is also used by those harmed by the alternatives presented and intending to preserve the preceding version of history. All of them demand for history reconstruction, but the "truth" (read: reconstruction) is only based on their own perspectives.

Historian, book writer, and educator of Indonesian history courses should reconsider how to organize more proper historical materials. So far, some of them straightforwardly use the documents without prior work process of critical historical methods to discover historical facts and evidence. The new direction of historiography affords Indonesian historians an opportunity to use nonconventional sources, such as space, model, daily life, people's names, street's names, song lyrics, music genres, sounds, poems, play scripts, paintings, caricature, movement, symbols, and signals. Therefore, the world of Indonesian history and education will be more interesting and valuable to learn.

Before turning out to be a scientist, a historian, a book writer, and a history teacher or lecturer have learned history courses from the elementary level, but the lesson did not function as encouragement to develop their skills, so that the condition of history as well as learning and teaching history can be described as preceded. 


\section{Reformulation of Organization of History Course Materials in Curriculum}

The phenomena clearly describe the urgency of historical education in constructing characteristics of the nation, human quality, and common Indonesian citizen. The condition is real, but to this point, its effectiveness is still being questioned since the phenomenon of life and youth's existence in the context of Indonesian nationality and realm gets more problematic. Hence, something needs to be fixed in delivering historical education (Alfian, 2007:1).

The effectiveness of historical education should be improved from curriculum, course materials, learning and teaching model, textbooks, and teacher professionalism. Some historical education experts and historians express their concerns in relation to this condition. According to Hamid Hasan in Alfian (2007) as cited by Martanto (2009), "today's reality suggests that historical education does not offer students any prospects to consider its correlation with present and future times. From elementary school to senior high school, learning and teaching process simply involves historical facts as the primary materials. Thus, it is generally considered that historical education seems empty and uninteresting and does not provide students any opportunities to interpret the values of certain historical events. On the other hand, Taufik Abdullah considers that pedagogical strategy of Indonesian history is terrible. Historical education at schools is generally associated with chronological approaches and demands for memorizing particular events (Abdullah in Alfian, 2007: 2). Students are not accustomed to interpret an event for understanding the dynamics of a transformation (Martanto, 2009).

Furthermore, Martanto describes, "The developed system of learning and teaching history is significantly correlated with the principal culture. Monodirectional model of learning and teaching, which makes use of teacher as a single source of references, has become a culture. The model ignores students' role as historical agents of their age. Students' prior experiences or their social environment are not comprised in course materials, so that the students become passive participants (Martanto, et al., 2009: 10). In other words, less accurate strategies of teaching will result in fatal consequences for the objectives (Widja, 1989: 13)."

Accordingly, to turn back the function and role of learning and teaching history as a process of constructing students' personality, all of us should make an evaluation, especially by organizing materials of historical education. Furthermore, it is carried on by mapping materials of analysis and both will be used as the basis for curriculum described more operationally as materials in the textbooks. These all are reflected in learning and teaching process with comprehensive strategies. In this phase, there should be various models of learning and teaching.

In historical education, historical phenomena and facts can be used as forms of learning and teaching media build competency. The statement is to assert 
that neither will be considered as the objective of learning and teaching process. If the facts become the objectives, the process will stuck in memorizing process and it may get worse as it is happening today, in which students are "deceived" to accept a single fact from a single dimension of thought. This suggests that the basic characteristics of learning and teaching history, such as interpretative and argumentative actions, will be blurred and become vulnerable to divergence in interpreting particular events. It may happen as the interpretation of history changes and students get confused since simultaneously they have to alter their understanding that is abruptly considered as inadequate by the new ruling regime, and vice versa.

In overcoming this phenomenon, organization of historical materials in curriculum, processes of learning and teaching, and textbooks, should be revised. It implies that the materials should be reorganized to cover whole aspects of life, not only on politics and nationality aspects. According to Daldjoeni (1981), it can be concluded that all aspects of life can be categorized into three dimensions; space, time, and norms/values or the order maintaining life in the world. History draws on time as the foundation of thoughts as all aspects of life "go" through it and facts and events will be aged. The age reflects dynamics and changes that is illustrated by the time.

The dimension of time demonstrates an understanding that human life always changes. The changes can be embraced by examining past development and correlating it with present condition to anticipate future possibilities. The dimension of space deals with human life in spatial context where the activities are performed and the resources are provided to survive. Through spatial assimilation, it is expected that every individual can expend, process, maintain and preserve natural resources as the main elements to fulfill biological and social needs to survive. The dimension of norms/values describes that there should be acknowledged principles, methods, and rules to survive and to make certain that everything goes in harmony.

The dimensions of time, space and norms/values have an effect on one another. A single event happened in particular space and time must be involved by time. Therefore, the examination of history cannot be separated from the dimension of space and norms. For example, examining natural (dimension of space) and cultural (dimension of values/norms) changes entail the usage of a map. It will invite students to analyze geographical background of particular events or facts of history. Consequently, history courses will not only involve an arrangement of years and names of figure. The essence of learning and teaching history is to understand the correlation between past events and today's situation, as well as their influences on future development in all aspects of human life (geography, economy, social, law, moral, ethics, and culture). That consideration can be illustrated in the diagram below: 
Chart 8.1. Correlation between past event and today's situation

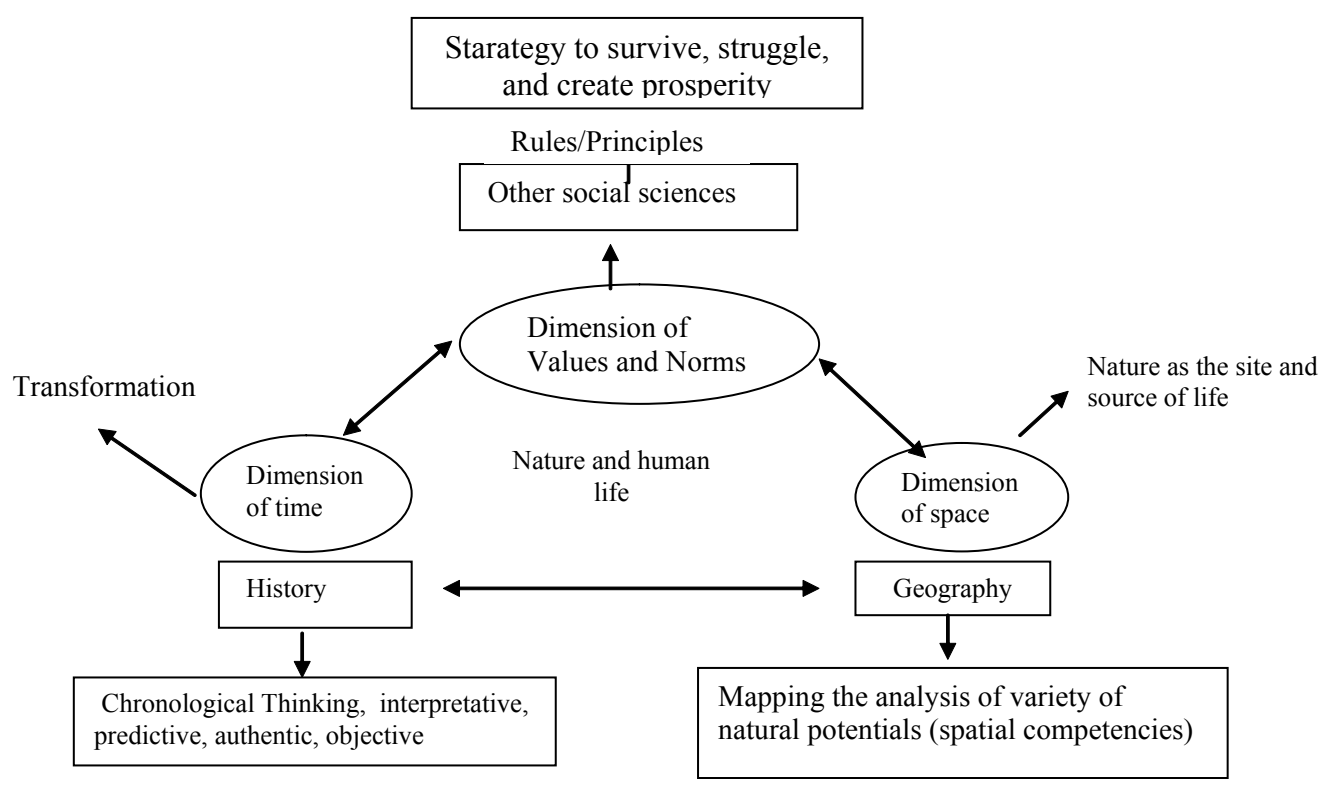

The diagram shows that the whole aspects of life analyzed in varied social sciences are closely related with history. If people understand the fundamental nature of time travel that influences all aspects of life, history courses will be the "major" or "central" point to understand the dynamics of other aspects. In this context, people recognize various concerns of history; history of politics, history of law, history of nature, history of economy, history of art, history of individual, history of a nation, etc. In this case, a set of historical events, phenomena, and heritage, such as artifacts, photos, documents, etc. can be used as media of learning and teaching history in appreciating the continuous and simultaneous processes of life. Thus, the focus of learning and teaching history is initiated by recognizing various sources of facts and events to discover authentic evidences, collect valid data, implement various techniques accepted in social science study, analyze the data, interpret the result, and draw some conclusions. Conclusions reached are supported by strong arguments. This series of methods fit in with the expectations to construct history courses, which is full of values of life for individual or general society.

This consideration fights for the equality of materials from various courses of social science that observes various aspects. For example, the outline of farming in Indonesia from colonial era to the early stage of demanding independence days can be analyzed in economic, geography, sociology, anthropology, and history courses. Each might be taught individually by different teachers or lecturers, but the topic can be discussed through similar thematic approaches that engaging historical facts as the central materials or object of analysis.

The actualization of that way of thinking will not only influence the patterns of learning and teaching history, but it will also affect the organization of other 
social science courses, such as geography, economics, sociology, anthropology, and civics. Thus far, each course of social science and its materials are away from each other. It seems like there is no correlation among all social science courses. History, economics, sociology and civics are separated, whereas the phenomena of life are closely related. This form of learning and teaching process results in students' inadequacy in understanding the condition of their nation as a whole.

\section{New Jersey Model}

A reference can be taken by observing other countries in organizing materials of history courses as the center of social science courses, similar to the organization in New Jersey, USA. All analysis materials of social science are oriented to the history of America as a whole.

Learning and teaching social studies functions to enhance students' awareness as American citizen and "Develop an increased depth of understanding of our global society, their understanding of the fundamental principles and values of American democracy and citizenship provides the conceptual framework that allows them to make informed decisions about local, national, and international issues and challenges." Accordingly, learning and teaching social studies are intended to develop one's competence, including his or her knowledge, skills, and thoughts required to generate active and creative students aware of their roles as citizens and making a contribution to local community. Social science serves to "provide learners with the knowledge, skills, and perspectives needed to become active, informed citizens, and contributing members of local, state, national, and global communities in the digital."

The integration is constructed and framed in 3 categories called content standard, i.e.: (1) U.S. History: America in the World (2) World History/Global Studies (3) Active Citizenship in the $21^{\text {st }}$ Century. Each standard is analyzed or examined through 4 perspectives named as strand consisting of: (1) Civics, Government, and Human Rights; (2) Geography, People, and the Environment; (3) Economics, Innovation, and Technology; and (4) History, Culture, and Perspectives. In the implementation of learning and teaching process, the four strands are combined with historical analysis in the context of era or classification of community development. The classification covers: (1) Three Worlds Meet (Beginnings to 1620, (2) Colonization and Settlement (1585-1763), (3) Revolution and the New Nation (1754-1820s), (4) Expansion and Reform (1801-1861), (5) Civil War and Reconstruction (1850-1877), (6) Colonization and Settlement (1585-1763), (7) Revolution and the New Nation (1754-1820s), (7) Expansion and Reform (1801-1861), (8) Civil War and Reconstruction (1850-1877), (9) The Development of the Industrial United States (1870-1900), (10) The Emergence of Modern America (1890-1930), (11) The Great Depression and World War II (1929-1945), (12) Postwar United States (1945 to early 1970s), (13) Contemporary United States (1970-Today), (14) Contemporary Issues. These historical analyses become the primary concerns of each strand analysis. 
Standardized course materials are given to all pre-school up to 12 grade students. These are learned to develop four types of basic skills that become the key points in developing competencies of social studies, i.e.: (1) chronological thinking, (2) spatial thinking, (3) critical thinking, and (4) presentational skills.

To keep the learning responsibility and level of difficulties upright with students' competence, the organization of materials is adjusted by categorizing students into 4 continuum stages: (1) Pre school -4 grade, (2) 5-8 grade, (3) 9-12. For Pre School to 4 grade students, the materials are given on the basis of strands. For 5-8 and 9-12 grade students the materials are not only based on strands, but also on era or classification of American community development. This organization can be noticed in the following table:

Table 8.1 Social Studies Curriculum of New Jersey

\begin{tabular}{|l|c|l|}
\hline \multicolumn{1}{|c|}{ Standard } & Grade Level & \multicolumn{1}{c|}{ Organization } \\
\hline \multirow{3}{*}{ U.S. History: America in the World } & P-4 & By strand only \\
\cline { 2 - 3 } & $5-8$ & By era and strand \\
\cline { 2 - 3 } & $9-12$ & By era and strand \\
\hline \multirow{2}{*}{ World History/Global Studies } & $5-8$ & By era and strand \\
\cline { 2 - 3 } & $8-12$ & By era and strand \\
\hline Active Citizenship in the 21st Century & $\mathrm{P}-4$ & By strand only \\
\cline { 2 - 3 } & $5-8$ & By strand only \\
\cline { 2 - 3 } & $9-12$ & By strand only \\
\hline
\end{tabular}

Source: New Jersey Core Curriculum Content Standards forSocial Studies

The objectives of social studies are to develop one's ability to implement his or her knowledge, skills, and attitude to become American citizen with nationalism and democracy awareness and be actively involved in world interaction. To make the process easier, the process of learning and teaching social studies is integrated with topics chosen from facts and reality of life valued as historical facts, focus and orientation of learning and teaching process. This approach helps students to appreciate the development of American nation from time to time and from varied perspectives.

Therefore, some basic skills, such as chronological, spatial, critical, and presentational thinking, simultaneously and comprehensively develop. Besides, the creation of nationalism spirit by appreciating history of the nation and setting an example from the prominent figures actively involved in the development of American nation from the early stage to present times will be much easier to be actualized. Learning and teaching social studies will be more valuable for life of students as decent American citizens. The four basic skills (chronological, spatial, critical, and presentational thinking) become the target of development as well as learning and teaching process and assessment related to the level of students' skill development. Below is the gradation of level of skills as the target of learning and teaching and assessment processes. 


\section{Table 8.2. Social Studies Skills}

\begin{tabular}{|c|c|c|c|}
\hline \multicolumn{4}{|c|}{$\begin{array}{l}\text { Social Studies Skills Table } \\
\text { Essential Question: What are effective strategies for accessing various sources of information } \\
\text { and historical evidence, determining their validity, and using them to solve a problem or find a } \\
\text { solution to a public policy question? }\end{array}$} \\
\hline $\begin{array}{l}\text { Social Studies } \\
\text { Skill }\end{array}$ & K-4 & $5-8$ & 9-12 \\
\hline $\begin{array}{l}\text { Chronological } \\
\text { Thinking }\end{array}$ & $\begin{array}{l}\text { Place key historical } \\
\text { events and people } \\
\text { in historical eras } \\
\text { using timelines. } \\
\text { - Explain how } \\
\text { the present is } \\
\text { connected to the } \\
\text { past. }\end{array}$ & 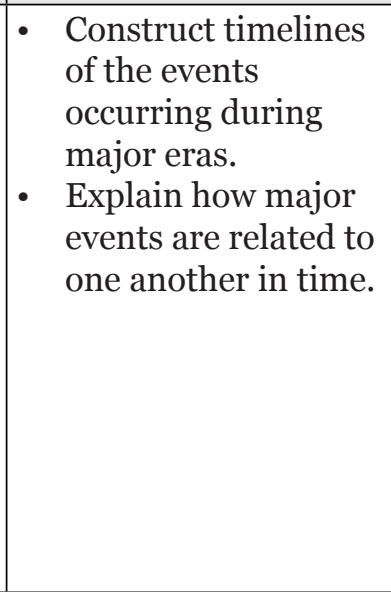 & $\begin{array}{l}\text { - Compare present and } \\
\text { past events to evaluate } \\
\text { the consequences of } \\
\text { past decisions and to } \\
\text { apply lessons learned. } \\
\text { - Analyze how change } \\
\text { occurs through time } \\
\text { due to shifting values } \\
\text { and beliefs as well } \\
\text { as technological } \\
\text { advancements } \\
\text { and changes in the } \\
\text { political and economic } \\
\text { landscape. }\end{array}$ \\
\hline Spatial Thinking & $\begin{array}{l}\text { Determine } \\
\text { locations of places } \\
\text { and interpret } \\
\text { information } \\
\text { available on maps } \\
\text { and globes. } \\
\text { - Use thematic } \\
\text { maps and other } \\
\text { geographic } \\
\text { representations to } \\
\text { obtain, describe, } \\
\text { and compare } \\
\text { spatial patterns } \\
\text { and information } \\
\text { about people, } \\
\text { places, regions, and } \\
\text { environments. }\end{array}$ & $\begin{array}{l}\text { - Select and use } \\
\text { various geographic } \\
\text { representations } \\
\text { to compare } \\
\text { information about } \\
\text { people, places, } \\
\text { regions, and } \\
\text { environments. } \\
\text { - Use maps and } \\
\text { other documents } \\
\text { to explain the } \\
\text { historical migration } \\
\text { of people, expansion } \\
\text { and disintegration of } \\
\text { empires, and growth } \\
\text { of economic and } \\
\text { political systems. }\end{array}$ & $\begin{array}{l}\text { Construct various } \\
\text { forms of geographic } \\
\text { representations to } \\
\text { show the spatial } \\
\text { patterns of physical } \\
\text { and human } \\
\text { phenomena. } \\
\text { Relate current events } \\
\text { to the physical and } \\
\text { human characteristics } \\
\text { of places and regions. }\end{array}$ \\
\hline Critical Thinking & $\begin{array}{l}\text { - Distinguish fact } \\
\text { from fiction. } \\
\text { - Identify and } \\
\text { use a variety } \\
\text { of primary and } \\
\text { secondary sources } \\
\text { for reconstructing } \\
\text { the past (i.e., } \\
\text { documents, letters, } \\
\text { diaries, maps, } \\
\text { photos, etc.). }\end{array}$ & $\begin{array}{l}\text { Compare and } \\
\text { contrast differing } \\
\text { interpretations } \\
\text { of current and } \\
\text { historical events. } \\
\text { - Assess the credibility } \\
\text { of sources by } \\
\text { identifying bias } \\
\text { and prejudice in } \\
\text { documents, media, } \\
\text { and computer- } \\
\text { generated } \\
\text { information. }\end{array}$ & $\begin{array}{ll}\text { - } & \text { Distinguish valid } \\
\text { arguments from false } \\
\text { arguments when } \\
\text { interpreting current } \\
\text { and historical events. } \\
\text { - Evaluate sources } \\
\text { for validity and } \\
\text { credibility and to } \\
\text { detect propaganda, } \\
\text { censorship, and bias. }\end{array}$ \\
\hline
\end{tabular}


HISTORIA:

International Journal of History Education, Vol. XI, No. 2 (December 2010)

\begin{tabular}{|c|c|c|c|}
\hline $\begin{array}{l}\text { Presentational } \\
\text { Skills }\end{array}$ & $\begin{array}{l}\text { Use evidence to } \\
\text { support an idea in a } \\
\text { written and/or oral } \\
\text { format. }\end{array}$ & $\begin{array}{l}\text { Select and analyze } \\
\text { information from a } \\
\text { variety of sources to } \\
\text { present a reasoned } \\
\text { argument or } \\
\text { position in a written } \\
\text { and/or oral format. }\end{array}$ & \begin{tabular}{|l} 
Take a position on a \\
current public policy \\
issue and support \\
it with historical \\
evidence, reasoning, \\
and constitutional \\
analysis in a written \\
and/or oral format.
\end{tabular} \\
\hline
\end{tabular}

Source: New Jersey Core Curriculum Content Standards for Social Studies

This approach affects the process of learning and teaching, the usage of sources, materials, and methods of learning and teaching, and the preparation of teacher. Learning and teaching process can be separately conducted among different courses, but all social studies teachers have to be complemented by the ability to formulate strategy and the approaches to design the integration of perspectives of basic knowledge of social studies in discussing social phenomena in the society. Thus, teachers will realize that social difficulties can be observed from various viewpoints. The usage of sources, materials, and methods of learning and teaching should be accordingly adjusted to students' competence, its characteristics and the social problems. The pattern is depicted in the following diagram:

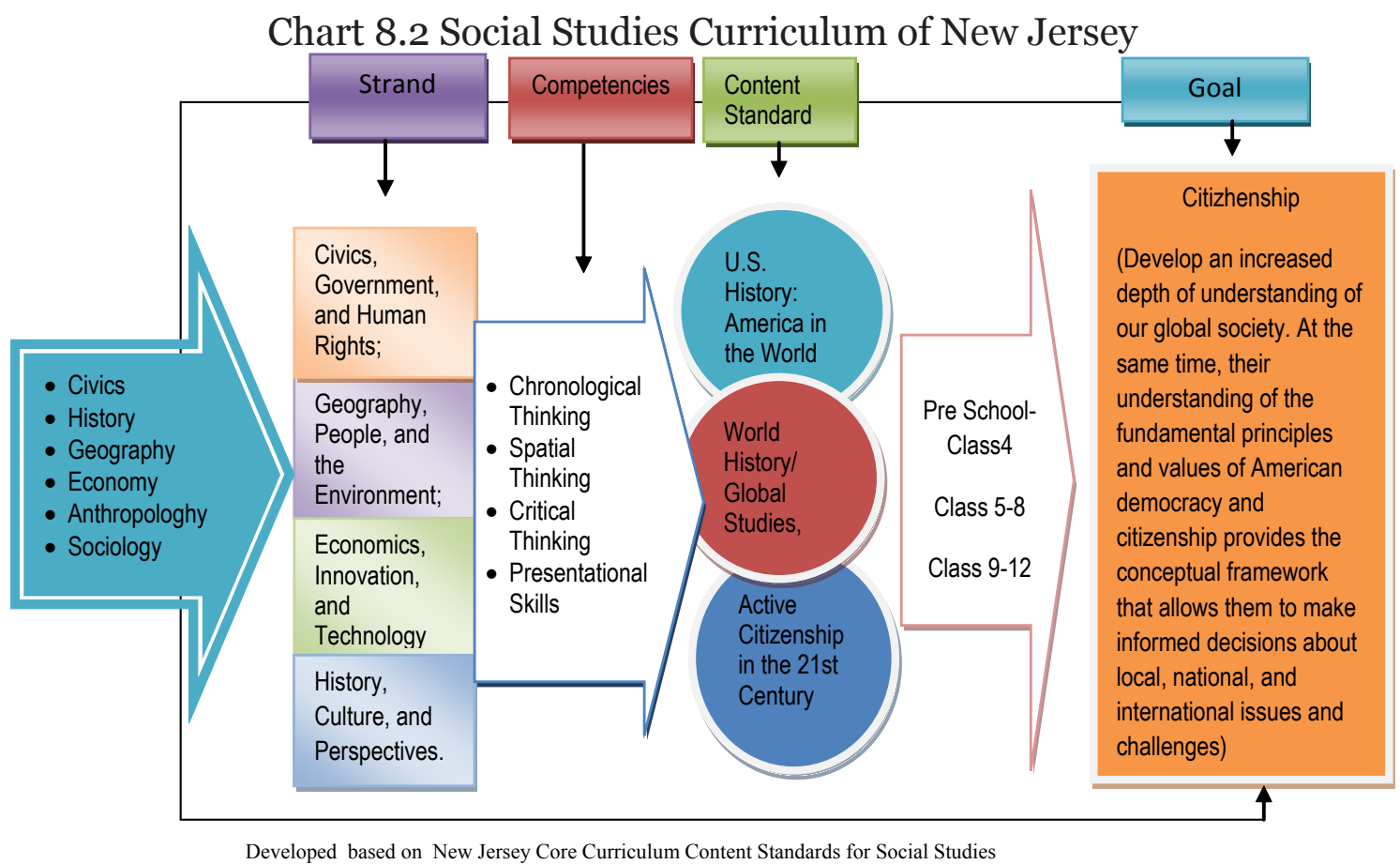

\section{Reformulation of Learning and Teaching Strategy}

Reformulation of organization of history course materials results in the necessity for reorientation of learning and teaching process to reformulate its 
curriculum and strategies. At elementary and secondary level of education, history courses is necessary to develop students' basic knowledge, skills, positive traits needed to become responsible citizen and be able to be actively contributed in social life as a part of the community and country. To achieve the target with specific methods and analysis in history courses, history itself serves a means to develop students' positive skills and attitude as a member of the community, society, and country. This is line with the objectives of education in constructing personality, independence, competence, and commitment to achieve the goal of life, individually or in a group of society.

The main target and the indicator for measuring the success of learning and teaching history is the alteration of students' attitude and behavior. According to the pillars of learning and teaching proposed and developed by UNESCO, learning is not only to know something, but also to make students do something, be something with their personality, and live together in harmony based on knowledge they gained. For that reason, learning and teaching history should be implemented constructively and based on consideration that each student has potential to develop independently. Hence, the primary concern of history courses as well as other courses is to motivate students to recognize their potential as early as possible by providing proper services so that they will be able to map and enhance their competence to deal with the reality of life and future challenges. However, the competence should be completed by a set of knowledge, skills, and positive attitude.

To develop their knowledge, students are provided with an easy access for information through various methods, for instance by directly observing, analyzing secondary data, facts, stories, and other attempts to train their sensitivity in observing phenomena, appreciating experience, and evaluating actions. Their knowledge will be filled in with basic facts, concepts, and theories. To develop their knowledge, there are several questions arising in each stage of learning and teaching, for instance:

- Why particular facts, concepts, and theories should be learned?

- Will understanding on the facts, concepts, and theories be of assistance to appreciate real life?

- Will the facts, concepts, and theories be relevant to skills and attitude constructed?

- Will the facts, concepts, and theories be of assistance to students to complete their competence?

The development is stimulated by opening up considerable opportunity and chances for students to implement or learn by doing it. Some basic skills in history can be classified into three categories: (1) thinking skill (logical, critical, anticipative, predictive, alternative, dialectic, systematic); (2) technical skill, including processing, inquiring, and communicating skills supported by other skills, such as observing, concluding, deciding, graphical interpreting, and classifying skills, that will help students in formulating strategies and alternatives to deal with problems/challenges; (3) social skill (also vocational) covering: 
interacting, actively-participating, productive, collaborative, discipline, and consistent skills.

Additionally, there are some models of skill development: (1) problemsolving model (defining problem, arising question(s) or hypothesis, analyzing, organizing, interpreting, and concluding), (2) decision-making model (identifying issues and alternative possibilities, designing a research, discovering/organizing/ interpreting information/data, making decision, and evaluating the decision).

The next step is attitude development. It can be applied based on one's habit and behavior that will become consistent practices. In consistent behavior, all components of knowledge and skills are reflected in one's attitude taken from the process of decision-making. Some specific reflections of attitude towards history are:

- Positive attitude to learn about how to become a professional person and responsible citizen in the community and country.

- Positive, objective, and realistic attitude to him or herself and others in the community.

- Hold different individual, community, or culture in respect, tolerance, mutual understanding, and empathy.

- Being democratic, appreciative, and consistent towards laws, rules, norms, and constitution as a reflection of a responsible citizen.

- Being logic, critical, optimistic, progressive, and argumentative in understanding life phenomena as a form of continuum of past, prest and future era.

There are some factors considered as the basis for organizing learning and teaching process to achieve the orientation of learning and teaching history:

\section{The Conformity with Students' Development and Necessity}

The design of learning and teaching process is demanded to be reliable with students' intellectual and social maturity. At Pre School and elementary level of education, history is mostly emphasized in the implementation and construction of students' attitude as responsible citizens in the surroundings, society, schools, and country. This is in line with students' level of maturity and process of personality construction.

\section{The Conformity with Dynamic Society's Development and Necessity}

Learning and teaching program prepares and adjust students to be actively involved in dynamic society and environment. It will encourage and enrich students' knowledge, skills, and attitude to set their place in the society and environment.

\section{The Contribution of each discipline}

Learning and teaching program consists of the reflection of implementation of historical, geographical, economic competence, and other social/humanitarian science based on students' level of maturity and development. 


\section{Learning Environment}

The focus of learning and teaching program is to create flexible conditions or environment for teachers to design programs based on students' necessity. Flexibility is also useful for the diversity of condition and availability of various learning and teaching tools, access, and media in line with particular environment and social life. Derived from concepts above, the strategy of learning and teaching history should be modified from mono-directional communication to more active movement. It is an attempt to develop students' competence in developing skills, knowledge, as well as understanding and case analysis from diverse dimensions of what is called as historical competence.

The followings are some examples of historical competence:

- Chronological understanding

This method can be implemented by training students to post a range of events in a time line in chronological order. Students are expected to use their own expressions. It is intended to teach them to think chronologically in their perspective, in addition to enrich their vocabularies and alternative thoughts.

- Knowledge understanding

This ability can be developed by training students to identify the reasons of why something happened, why people did it, why it could happen, what the effects are, etc.

- Historical interpretation

The interpretation can be developed by making interpretation in various ways and accounts. This process will encourage the development of students' ways of thinking in drawing conclusion and taking an action.

- Historical enquiry

This is a form of self-study to recognize various supporting aspects and data to interpret assorted past events and correlate them to present condition. This method can be implemented by making questions and answering them by oneself.

- Organizing and communicating

This is implemented to train students to express and communicate their conclusion through sayings, pictures, caricature, or writings.

- Case study

This form of study is emphasized to discuss local or individual history of oneself, one's family, or local community.

\section{Conclusion}

The lack of credit and appreciation for history of the nation especially among students comes not only from mono-directional process of learning and teaching, but also from the domination of indoctrination in contrast with creativity 
development. Thus, to fix this condition there should be a reformulation of curriculum and process of learning and teaching by implementing new paradigm, i.e. materials of history courses related to historical events, phenomena, and heritage are used as development media of historical competence. All this time, the materials are merely objectives of the process, but this consideration tends to make students only memorize them than to understand and appreciate them through objective attitude.

A natural occasion will be a historical fact as it is correlated to former and later occasions. It shows that a historical fact is interpretative, argumentative, predicative, and sensitive, so that one should have ability to recognize authentic facts, correlate some chronological events, and collect arguments as the basis of prediction and interpretation before drawing an objective conclusion. That ability is called historical competencies, and it should immediately be taught to students through the process of learning and teaching history. This implementation will prevent the continuity of monotonous and unexciting process of learning and teaching history that will come to anticlimax results; the lack of appreciation to the history of the nation.

As a result, the main concern of historical education is not about historical facts, but it is about the process of transforming the competence to learn history from one generation to the next generation. Therefore, this phenomenon has to be considered by historian and history teachers and lecturers since they all are correlated one another.

\section{REFERENCES}

Alma, B. and Harlasgunawan (ed). (1987). Hakekat Studi Dasar Ilmu Sosial. Bandung, Sinar Baru

Cairns, R.B. (1933), Social Development, USA, Freeman and Company

Cartledge and Milburn. (1980). Teaching Social Skills to Children, Innovative Approaches. Paris. Pergamon General/ Psychology series.

Daldjoeni, N. (1981). Dasar-Dasar Ilmu Pengetahuan Sosial: Buku Pengantar Bagi Mahasiswa dan Guru, Bandung, Alumni

Dryden, G and Vos. (1999). Revolusi Cara Belajar (1-2). Bandung, Mizan, Hamalik, O. (1992). Studi Ilmu Pengetahuan Sosial, Bandung, Mandar Maju http://www.polarhome.com/pipermail/marinir/attachments/20070110/ e27ceecd/attachment-oo01.pdf

Levine, D.U, (et.al). (1989). Society and Education. USA, Alyn and Bacon.

Martanto, S.D. (2009), Pembelajaran Sejarah: Permasalahan dan Solusinya, Makalah http://suciptoardi.wordpress.com/2009/07/28/pembelajaransejarah-permasalahan-dan-solusinya/

McBeath, C. and Dellar, G. (1995). Curriculum \& Evaluation, Study Guide. Perth: Curtin University of Technology.

Menteri Pendidikan Nasional (2006). Peraturan Menteri Pendidikan Nasional Nomor 22, 23, dan 24 tahun 2006. 
New Jersey Core Curriculum Content Standards for Social Studies www.state. nj.us/education/cccs/2009/std6_ss.doc

Print, M. (1993). Curriculun Development and Design. NSW Australia, Allen \&Unwin

Purwanto, B. (2006). Gagalnya Historiografi Indonesiasentris?. Makalah.

Sunaryo. ( 1989). Strategi Belajar Mengajar Ilmu Sosial. Malang: IKIP Malang 